See Article page 183.

\section{Commentary: Carbon dioxide embolism during vein harvesting-Directed transesophageal echocardiography for diagnosis and hemodynamic rescue}

\author{
John G. Augoustides, MD, FASE, FAHA
}

Endoscopic saphenous vein harvesting has matured as a minimally invasive technique for vascular conduit during coronary artery bypass grafting. ${ }^{1}$ The complications of this technique include gas embolism. ${ }^{2-4}$ The roles of transesophageal echocardiography in the management of this catastrophic complication can be lifesaving. 3,4

The case reported by Kawabori and colleagues ${ }^{5}$ in this issue highlights the central role of transesophageal echocardiography in this setting. During conduit harvest, significant carbon dioxide embolism resulted in cardiac arrest. The vigilant team instituted prompt cardiopulmonary bypass and echocardiographic-directed management. The case was complicated by right ventricular failure, requiring aggressive pharmacologic support and delayed sternal closure. The patient had a complete recovery, with no neurologic sequelae.

How might this case inform the conduct of endoscopic vein harvest in light of the current literature? One option is to avoid an endoscopic approach in select patients, given its reported reduced graft patency. ${ }^{6}$ This decision could be

From the Cardiovascular and Thoracic Section, Department of Anesthesiology and Critical Care, Perelman School of Medicine, University of Pennsylvania, Philadelphia, Pa.

Disclosures: The author reported no conflicts of interest.

The Journal policy requires editors and reviewers to disclose conflicts of interest and to decline handling or reviewing manuscripts for which they may have a conflict of interest. The editors and reviewers of this article have no conflicts of interest.

Received for publication Jan 30, 2020; revisions received Jan 30, 2020; accepted for publication Feb 3, 2020; available ahead of print Feb 23, 2020.

Address for reprints: John G. Augoustides, MD, FASE, FAHA, Cardiovascular and Thoracic Section, Department of Anesthesiology and Critical Care, Dulles 680, HUP, 3400 Spruce St, Philadelphia, PA 19104-4283 (E-mail: yiandoc@ hotmail. com).

JTCVS Techniques 2020;3:188-9

2666-2507

Copyright (C) 2020 The Authors. Published by Elsevier Inc. on behalf of The American Association for Thoracic Surgery. This is an open access article under the CC BY-NCND license (http://creativecommons.org/licenses/by-nc-nd/4.0/).

https://doi.org/10.1016/j.xjtc.2020.02.010

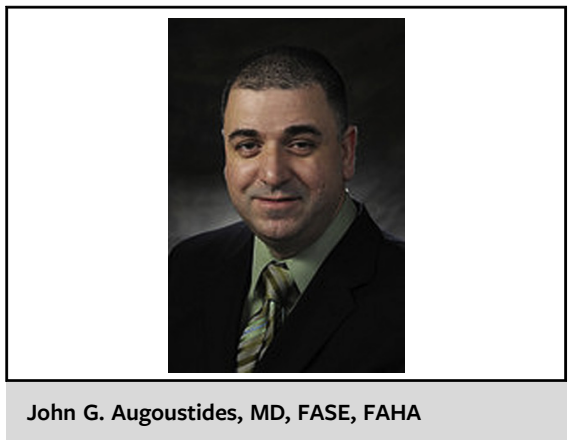

CENTRAL MESSAGE

Massive carbon dioxide embo-

lism is a rare complication of

endoscopic saphenous vein har-

vest. Transesophageal echocar-

diography can guide diagnosis

and management.

guided by a new risk score for saphenous vein graft failure. Further trials will refine the conduct of saphenous vein harvest to enhance patency, including attention to a no-touch technique. ${ }^{8,9}$

What are our options when an endoscopic approach is selected for vein harvest? Clearly, meticulous technique with careful carbon dioxide insufflation remains essential. ${ }^{1-3}$ Transesophageal echocardiography can allow rapid diagnosis of gas embolism, as exemplified by this case. Although this diagnostic modality is still debated in coronary artery bypass grafting, it should be available to evaluate hemodynamic compromise. ${ }^{3,4,10}$ The midesophageal bicaval view can capture the passage of gas emboli and suggest the likely source..$^{3-5}$ If the gas emboli access the right atrium through the inferior vena cava, the source is below the diaphragm. ${ }^{5,11}$ If the gas emboli access the right atrium from the superior vena cava, the source is above the diaphragm. $^{3-5}$

Furthermore, in gas embolism, the right atrial pressure is commonly elevated..$^{3-5}$ Right coronary ischemia is common, resulting in bradycardia and right ventricular failure. ${ }^{3-5}$ The right atrial hypertension may stretch a patent foramen ovale to allow right-to-left shunting, which can be reduced with medical and surgical interventions. ${ }^{3-5,12,13}$

So, where do we go from here? This complex case has focused attention on transesophageal echocardiography for hemodynamic rescue in carbon dioxide embolism. ${ }^{5}$ It can reliably diagnose this complication and guide an integrated management response. ${ }^{3-5}$ In this case, the heart team 
proceeded with bicaval cannulation for cardiopulmonary bypass. The inferior vena caval cannula coupled with a snare provided a prompt route for clearance of gas emboli. The data from transesophageal echocardiography can also guide the escalation of support for the failing ventricle. ${ }^{14,15}$

In conclusion, Kawabori and colleagues ${ }^{5}$ are to be congratulated for highlighting the integrated management of carbon dioxide embolism. The vigilant heart team should include transesophageal echocardiography in the response to this complication. ${ }^{3-5}$ A multimodal approach is typically required for hemodynamic rescue and subsequent ventricular support. ${ }^{3-5,14,15}$ Future trials will likely refine the conduct of endoscopic vein harvesting, which may further minimize the risk of this complication.

\section{References}

1. Genovesi MH, Roberrtazzi RR, Vitali RM, Connolly M, Subramanian VA. Recent progress in minimally invasive conduit harvesting. Semin Thorac Cardiovasc Surg. 2002; 14:82-8.

2. Lin TY, Chiu KM, Wang MJ, Chu SH. Carbon dioxide embolism during endoscopic saphenous vein harvesting in coronary artery bypass surgery. J Thorac Cardiovasc Surg. 2003; 126:2011-5.

3. Fan L, Denisco D, Knorz DL, Mapes RM, Nader ND. A case report of a carbon dioxide embolism caused by endoscopic vein harvesting during cardiac surgery. Korean J Anesthesiol. 2012;63:161-4.

4. Mommerot A, Peraault LP. Carbon dioxide embolism induced by endoscopic saphenous vein harvesting during coronary artery bypass grafting. J Thorac Cardiovasc Surg. 2006;132:1502. author reply 1502-3.

5. Kawabori M, Kinford C, Ortoleva J, Couper GS. Cardiac arrest from massive carbon dioxide embolism during endoscopic saphenous vein harvesting. J Thorac Cardiovasc Surg Tech. 2020;3:183-5.
6. Kodia K, Patel S, Weber MP, Luc JGY, Choi JH, Maynes EJ, et al. Graft patency after open versus endoscopic saphenous vein harvest in coronary artery bypass grafting surgery: a systematic review and meta-analysis. Ann Cardiothorac Surg. 2018;154:586-97.

7. Antonopoulos AS, Odutayo A, Oikonomou EK, Trivella M, Petrou M, Collins GS, et al; SAFINOUS-CABG (Saphenous Vein Graft Failure-An Outcomes Study in Coronary Artery Bypass Grafting) group. Development of a risk score for early saphenous vein graft failure: an individual patient data meta-analysis. J Thorac Cardiovasc Surg. August 26, 2019 [Epub ahead of print].

8. Dreifaldt M, Mannion JD, Geijer H, Lidén M, Bodin L, Souza D. The no-touch saphenous vein is an excellent conduit to the radial artery 8 years after coronary artery bypass grafting: a randomized trial. J Thorac Cardiovasc Surg. October 26, 2019 [Epub ahead of print].

9. Burns DJP. Commentary: better prediction, better execution, better management. J Thorac Cardiovasc Surg. August 22, 2019 [Epub ahead of print].

10. MacKay EJ, Werner RM, Groeneveld PW, Desai ND, Reese PP, Gutsche JT, et al Transesophageal echocardiography, acute kidney injury, and length of hospitalization among adults undergoing coronary artery bypass graft surgery. J Cardiothorac Vasc Anesth. 2020;34:687-95.

11. Kale RD, Sarwar MF, Sopchak A. Intraoperative massive carbon dioxide embolism captured with transesophageal echocardiography in a patient with a rare vena cava anomaly. J Cardiothorac Vasc Anesth. 2019;33:157-61.

12. Patel PA, Hall A, Augoustides JGT, Patel S, Feinman JW, Weber B, et al Dynamic shunting across a patent foramen ovale in adult cardiac surgeryperioperative challenges and management. J Cardiothorac Vasc Anesth. 2017; 32:542-9.

13. Ramakrishna H, Patel PA, Gutsche JT, Kohl BA, Savino JS, Augoustides JG Incidental patent foramen ovale in adult cardiac surgery: recent evidence and management options for the perioperative echocardiographer. J Cardiothorac Vasc Anesth. 2014;28:1691-5.

14. Bhama JK, Bansal U, Winger DG, Teuteberg JJ, Bermudez C, Kormos RL, et al Clinical experience with temporary right ventricular mechanical circulatory support. J Thorac Cardiovasc Surg. 2018;156:1885-91.

15. Kwak J, Majewski MB, Jellish WS. Extracorporeal membrane oxygenation: the new Jack-of-all-trades? J Cardiothorac Vasc Anesth. 2020;34:192-207. 